\title{
Prostitution laws: health risks and hypocrisy
}

C anadian law on prostitution has changed little since our first Criminal Code outlawed "bawdy houses," procuring and living on the avails of prostitution; then as now, the Criminal Code did not prohibit the buying and selling of sexual services. But these longstanding laws against prostitution are largely unenforced, as anyone consulting the yellow pages under "escort services" will realize. In fact, most municipalities gave up on enforcement long ago, turning instead to regulation, licensing and, as for all commercial establishments, taxation. As citizens we all live off the avails.

A more recent law, however, is enforced. In 1985 the federal government passed a new prostitution control measure that prohibits communicating in a public place for the purpose of buying and selling sexual services. This "communication provision" (which serves to underscore the hypocrisy of our prostitution laws) was designed to deal with the visible nuisance of street prostitution - and, undoubtedly, to protect property values.

Apart from the legal paradox - it is legal to buy and sell sexual services, but not to communicate about the transaction - the law in its application favours the client and puts young girls working on the street at risk. When prospective clients are convicted of the criminal offence of "communicating" they are, unlike the prostitutes themselves, rarely jailed. They are required to go to "john school," not to address the question of a public nuisance violation, but to attend a one-day "morality play on prostitution."

Foremost among the health risks of prostitution is premature death. In a recent US study of almost 2000 prostitutes followed over a 30-year period, by far the most common causes of death were homicide, suicide, drug- and alcohol-related problems, HIV infection and accidents in that order. The homicide rate among active female prostitutes was 17 times higher than that of the age-matched general female population. ${ }^{2}$

In his thoughtful and comprehensive review of Canadian prostitution law, ${ }^{1}$ John Lowman of the School of Criminology at Simon Fraser University identifies a "twotier" sex trade in Canada: "a licensed off-street trade, and a black-market [on-street] trade." Women (mostly of legal age, over 18) in relatively stable living situations work in the licensed and regulated off-street sex-trade in relative safety from abusive clients and free of police prosecution, while young girls, frequently homeless, must fight it out on the streets with both clients and police.

They live precarious lives. Often less than 18 years of age, most have few qualifications for other work. Many, for various reasons - poverty, mental illness, homelessness, a history of childhood abuse - turn to prostitution as the only way to survive and pay for their basic needs. Drug addiction, when it has not been the cause of their dropping out from school and home, frequently develops, making it even more difficult to find safer employment.

Targetted by police who enforce the communication laws, street prostitutes must conclude too-hasty negotiations with their customers (often climbing into the client's car); if violence or robbery ensues, they rarely report the incident to the police for fear of being prosecuted and jailed. As well, street prostitutes are more likely to encounter men whose intention is violence or a combination of sex and violence. These men avoid regulated off-street prostitutes because of the ease with which they can usually be identified during the negotiations and payment for sexual services. Most $(80 \%)$ of the prostitutes murdered in British Columbia between 1975 and 1994 worked on the streets. ${ }^{3}$

In its recently released comprehensive report and broad set of recommendations, Prostitution de rue, ${ }^{4}$ Quebec's Conseil permanent de la jeunesse urges that society exchange its moral hypocrisy for a harm-reduction approach. In addition to a broad range of recommendations that tackle the important issues surrounding street prostitution poverty, schooling, health care, drug treatment, community policing, etc. - the report recommends a repeal of the communication laws against both prostitutes and their clients. Physicians should urge federal politicians to repeal all prostitution laws, as Lowman recommends, and start over again. Municipalities and public health and community physicians must work harder to protect this vulnerable population. - CMAJ

\section{References}

1. Lowman J. Prostitution law reform in Canada [1997]. Available: http://mypage .uniserve.ca/ lowman/ProLaw/prolawcan.htm (accessed 2004 June 28).

2. Potterat JJ, Brewer DD, Muth SQ, Rothenberg RB, Woodhouse DE, Muth JB, et al. Mortality in a long-term open cohort of prostitute women. Am 7 Epidemiol 2004;159:778-85.

3. Lowman J, Fraser L. Violence against persons who prostitute: the experience in British Columbia. Department of Justice Canada Technical Report TR1996$14 \mathrm{e}, 1996$.

4. Prostitution de rue : avis. Conseil permanent de la jeunesse, Gouvernment du Québec. April 2004. 